\title{
Service Retail Results Assessment from the Consumer's Point of View
}

\author{
Avaliação de Resultados no Varejo de Serviço sob a Ótica do Consumidor \\ Evaluación de los Resultados de Servicio al por Menor Según la Perspectiva del \\ Consumidor
}

\section{Eliane Cristine Francisco-Maffezzolli ${ }^{1}$ \\ Paulo Henrique Muller Prado ${ }^{2}$}

Received on December 29, 2011 / Approved on March 11, 2013

Responsible Editor: João Maurício Gama Boaventura, Doctor

Evaluation Process: Double Blind Review

\begin{abstract}
This study aims at assessing the connection between financial results and non-financial assessments from the consumer's point of view, considering Brazil's mobile phone context. According to consumer relationship theory, higher profits are to be expected from satisfied customers, from those who tend towards long-term use of company services. Therefore, non-financial assessments such as satisfaction, commitment, trust and loyalty were correlated to financial results, according to consumption information reported by consumers themselves. Altogether, 493 cases were investigated in a non-probabilistic sample of customers belonging four different mobile phone operators. The relationship quality assessment model was confirmed, although the expected connection between satisfaction, loyalty and financial results was not observed. Results
\end{abstract}

obtained suggest sector-specific assessments, in which mobile phone user behavior is not revealed in a linear way. Findings suggest new perspectives for relationship quality analysis applied to customers within growing markets that harbor a wide range of offers amongst competitors.

Keywords: Relationship quality. Service retailing. Financial result.

\section{RESUMO}

O presente estudo se propóe a avaliar a relação entre resultado financeiro e avaliação não financeira sob a ótica do consumidor, considerando o contexto de telefonia celular brasileiro. De acordo com a teoria de relacionamento com o consumidor, é esperada maior rentabilidade de clientes satisfeitos e que tenham perspectiva de longo prazo com o uso dos serviços da empresa.

1. Doctor in Management by Universidade Federal do Paraná - UFPR. Professor at the Pontifícia Universidade Católica do Paraná - PUC/PR. [eliane.francisco@gmail.com]

Author's address: Rua Imaculada Conceiçấo - Prado Velho, Curitiba - PR Cep. 80215-901 - Brazil

2. Doctor in Business Management by the Fundação Getúlio Vargas - FGV/SP. Professor at Universidade Federal do Paraná - UFPR. [pprado@ufpr.br]

Author's address: Rua Professor Lothário Meissner, 632 - Jardim Botânico, Curitiba - PR Cep. 80210-170 - Brazil 
Para isso, avaliações não financeiras, como satisfação, comprometimento, confiança e lealdade foram relacionadas com o resultado financeiro de acordo com informaçôes de consumo declaradas por consumidores. Foram pesquisados 493 casos em caráter não probabilístico entre clientes de quatro operadoras de telefonia celular. O modelo de avaliação foi corroborado, embora a relação esperada entre satisfação e lealdade com o retorno financeiro não tenha sido observada. Os resultados encontrados sugerem avaliaçôes específicas do setor, em que o comportamento do usuário de telefonia celular não se mostra de forma linear. Os achados sugerem novas perspectivas de análise de qualidade do relacionamento para clientes de mercados em expansão que contam com vasta oferta entre concorrentes.

Palavras-chave: Qualidade do relacionamento. Varejo de serviço. Resultado financeiro.

\section{RESUMEN}

Este estudio pretende evaluar la relación entre los resultados financieros y la evaluación no financiera desde la perspectiva del consumidor, teniendo en cuenta el contexto de la telefonía móvil en Brasil. De acuerdo con la teoría de relación con el consumidor, se espera que se produzca una mayor rentabilidad de clientes satisfechos además de obtener perspectiva a largo plazo en el uso de los servicios de la empresa. Para ello, resultados no financieros, como las evaluaciones de satisfacción, el compromiso, la confianza y la fidelidad fueron relacionados con los resultados financieros de acuerdo a la información de consumo presentados por los consumidores. Un total de 493 casos se analizaron de manera no probabilística entre los clientes de cuatro operadores de telefonía móvil. El modelo de evaluación de calidad de la relación quedó confirmado, aunque no se observó la relación esperada entre la satisfacción y la fidelidad con el retorno financiero. Los resultados apuntan evaluaciones específicas en el sector de la telefonía móvil, donde el comportamiento de los usuarios no es lineal. Los resultados indican nuevas perspectivas para el análisis de la calidad de la relación de los clientes en mercados en crecimiento que tienen gran variedad de competidores.

Palabras clave: Calidad en la relación. Servicio al por menor. Resultado financiero.

\section{INTRODUCTION}

The connection between customer base management and company financial results is a crucial topic to be studied in service retail companies. After all, since consumers tend to behave differently according to services they use and to how intensely they use them, different revenues are produced by different customers, as well as different ways of perceiving their satisfaction and loyalty.

It is generally accepted that a satisfied customer tends to be loyal and that this results in better revenues for the company (OLIVER, 1999). Hence, one of the most frequently asked questions amongst managers is: how can these results be approached altogether, so as to produce information that is useful to strategic marketing?

Beyond this practical aspect, the relevance of research and other contributions in the field of marketing productivity and, specifically, of relationships that impact financial and nonfinancial results is pointed out by authors such as Guo and Jiraporn (2005), Yeung and Ennew (2000), Calciu and Salerno (2002), Reinartz and Kumar (2003), and Sampaio et al. (2011), amongst others.

In order to make research illustrating these relationships feasible, we decided to verify how - from the relationship marketing perspective - the evaluation of relationship quality and loyalty concepts (here approached as non-financial results) refers to revenue produced by the customer (LTR - Lifetime Revenue, here approached as financial income). Literature on the loyalty concept suggests that these variables do possibly have a positive and significant impact 
on revenues (REICHHELD; SASSER, 1990; FORNELL, 1992).

Thus, this study proposed an adaptation of the structural model suggested by Prado (2004) on relationship quality, adding a financial result variable represented by revenue produced by the customer. The empirical context employed was that of mobile service retail. This sector was chosen for two main reasons: (1) this service is approached from a relationship perspective, considering consumers acquire mobile lines and tend to use them over a medium- to long-term period; and (2) due to sector characteristics, which reveal optimistic growth figures according to data from Teleco ([2011]) (232 million active lines by December 2011, 54\% over figures from the same period in 2008), despite the customer instability that results from changing service providers.

The context observed in mobile operators raises some important questions, such as: what can be expected from customers in view of services offered? Based on this assessment, what result can be expected; i.e., which indexes are capable of guiding efficient customer base management?

Thus, the goals of this research were as follows: (1) to verify the connection between the components of relationship quality (satisfaction, trust and commitment) and loyalty; (2) to determine the calculation model for financial result; and (3) to examine the influence of relationship quality and loyalty components on the financial result index in service retail.

The main findings of the study reveal how relevant relationship quality is to evaluating

services provided by surveyed operators, and also suggest a simplified way of calculating customer value. The relationship with each customer's profitability, however, was not observed in a direct and linear way, as is common in literature.

\section{THEORETICAL REFERENCES}

This research briefly contextualizes the retail sector of services chosen for empirical study. Subsequently, we review concepts presented in the structural model developed whilst carrying out research, and deduce hypotheses to be tested.

\section{I Service retail}

Service retail is a service activity in which consumers do not acquire ownership of the goods purchased, only its benefits (PARENTE, 2000). According to the author, this is an activity that has grown increasingly in economy and in the lives of consumers.

Kotler (2000) defines this service as an essentially intangible act or performance that one party can offer to another and that does not result in ownership of anything physical. Therefore, carrying out a service may or may not be connected to a concrete product. Added to this definition, the author highlights four characteristics - intangibility, inseparability, variability and perishability.

Thus, services offered by mobile operators are a type of service retail. Despite a certain physical logic when purchasing a device and a phone number, after this purchase the consumer now has a direct relationship with the operator. This is when, for example, the mobile account starts to be directly discounted from the customers' bank accounts - and when they now count on the operator's website or call center services. In this sense, research is focused on the direct relationship between customers and their service operators.

\subsection{Brief history of mobile service retail in Brazil}

The mobile phone market has shown significant changes over recent years due to technological advances, increasing competition and changing consumer behavior. According to Teleco $^{1}$ statistics ([2011]), 232 million active lines were registered in 2011 (by December). This figure reveals a $54 \%$ increase compared to 2008 . However, the proportion of line types (prepaid and postpaid) remained similar: $81.62 \%$ of active lines in Brazil are prepaid.

This growth and market expansion scenario justifies actions to monitor customers' 
relationships with companies and to maintain profitable consumers. Also according to information disclosed by Teleco ([2011]), because prepaid users' average revenue per user $\left(\mathrm{ARPU}^{2}\right)$ is, in certain operators, seven times lower than that of postpaid users, we began to put more emphasis on acquisition and on loyalty of higher consumption users, promoting control plans which are intermediate between post and prepaid plans.

Amongst active operators in Brazil, companies' market share registered, by October 2011, respectively: Vivo (29.6\%), Tim (26.0\%), Claro (25.2\%), Oi (18.9\%), and others (0.3\%). Amongst these, Vivo, Tim and Claro account for the largest share since 2008.

Results from companies in this sector can be understood by observing the ARPU in detail - the average of all active companies by the third quarter of 2011 reached the monthly value of $\mathrm{R} \$ 21.8$. Over the same period, Vivo had the highest ARPU: being R \$ 26.2. The lowest value ( $R$ \$ 17.0) was Claro's. regarding operating performance, we observed that, by the end of the third quarter of 2011, Vivo had registered 67.038 million lines, suggesting a profitability base over R\$ 1 billion (estimate from ARPU multiplied by number of lines). Added to this impressive performance by the sector, we must, however, consider change rates, estimated monthly at 3.7\%. Again, Vivo appears best placed amongst the top four companies in the market: with the lowest rate of $2.9 \%$, followed by Tim, at $3.9 \%$, Claro, at $4.0 \%$, and $\mathrm{Oi}$, at $4.1 \%$.

\subsection{Relationship quality and loyalty}

According to Henning-Thurau and Klee (1997), relationship quality is the measure of a relationship's adequacy in meeting the needs of individuals/customers - thus taking into account the constructs of trust, commitment and quality as mediators of consumer satisfaction and retention . Prado (2004), following the logic of antecedent- consequent relationships between satisfaction and perceived quality, proposed an adjustment to this concept, made up by three variables: satisfaction, trust and commitment. This research used this second version.

In this way, the relationship quality construct is used as a second-order variable and it is measured individually in each latent variable which comprises it. This is why we define concepts used in variables and relationships between them.

Customer satisfaction has been widely studied in marketing since the 1960s (OLIVER, 1981). The concept that is commonly elaborated on by authors in the field deals with the subjective comparison (or assessment) of expected and received levels of experience referring to the product or the service (OLIVER, 1981; SOLOMON, 2002; ENGEL; BLACKWELL; MINARD, 2000), which refers to the paradigm of variance.

To the cumulative concept attributed to satisfaction from the relationship perspective, we add the fact that the previously commented on composition referring to relationship quality is similar to that proposed in Prado's research (2004). To this author, individuals who are more satisfied tend to believe in suppliers and commit to them. Baptista, Silva and Goss (2011) demonstrate that there is a positive relationship between satisfaction and trust in the context of free download sites. Sampaio et al. (2011) comment on satisfaction and commitment as measures of consumer perception that are connected to the product/ service/ brand experience. Thus, we tested the relationships between satisfaction and the other two constructs, namely trust and commitment:

H1: The greater the satisfaction, the greater the trust in the service supplier. $\mathrm{H} 2$ : The greater the satisfaction, the greater the commitment to the service supplier.

Trust is the idea of confidence and reliability between partners in a relationship (GARBARINO; 
JOHNSON, 1999; GRÖNROOS, 1990). This variable is considered a key ingredient to the success of a relationship (GARBARINO; JOHNSON, 1999; DWYER; SCHURR, OH, 1987; MORGAN; HUNT, 1994). As proposed by previous studies (SIDERSHMUKH; SINGH; SABOL, 2002; PRADO, 2004), trust is a basis for loyalty, since it reduces perceived risk within a relationship - and, as such, we present hypothesis 3, wherein:

H3: The greater the trust, the greater the loyalty.

Commitment is defined by literature as the desire to continue in a relationship (WILSON, 1995) and has been used as a good index of lasting (long-term) relationships between customers and companies (DWYER; SCHURR, $\mathrm{OH}, 1987$; SAMPAIO et al., 2011). This variable is commonly studied in interorganizational and intraorganizational environments (MAVONDO; RODRIGO, 2001).

The relationship between trust and commitment was outlined as relevant and positive in research by Morgan and Hunt (1994) and Prado (2004). According to the authors, trust is believed to be key to relationship commitment. Since our research deals with a highly competitive environment (technological development and intense competition, amongst others), we expect this connection to be - as well as positive $-\mathrm{a}$ measure of increasing loyalty to the relationship. Thus, we present hypotheses 4 and 5:

H4: The greater the trust in the service supplier, the greater the commitment. $\mathrm{H} 5$ : The greater the commitment to the service supplier, the greater the loyalty.

Loyalty refers to consumers' judgement that a company is their best choice (OLIVER, 1999). A person's feelings of belonging to a company, product or service - as well as their affection for this company - can also be added to the concept of loyalty (JONES, SASSER, 1995).
To a company, consumers' revenues can come in the short, medium and long term. Generally, short term is associated with increased sales. Medium and long term are associated with brand value and customer base assets (STEWART, 2009).

Loyalty plays a relevant role mainly in assessments that require more time. Individuals are loyal when they show greater interest and repurchase the product/brand. Thus, this is a key variable in assessing commercial relationships as to medium and long-term, brand value and frequent and profitable customer portfolio. Long-term behavior results from the constant satisfaction that sustains the desire to remain with the same supplier.

In this way, as observed by other studies (PRADO, 2004; BAPTISTA, 2005), satisfaction is an important factor and a basis for loyalty, a fact which supports hypothesis 6:

H6: The greater the satisfaction index, the greater the loyalty.

\subsection{Financial result}

The assumption initially used as financial result was based on a perspective - of attracting and keeping consumers - from research concerning consumers' lifetime revenues. Thus, a profitable consumer is one whose revenue produced during the business relationship exceeds the costs of attracting and keeping him (CALCIU; SALERMO, 2002).

The attempt to associate company investments (with an emphasis on marketing practices) and revenues obtained is approached in various ways by authors. Berger and Nasr (1998) believe that a customer's lifetime revenue is a way of measuring the relationship: "to find out if a relationship is profitable or not, the company must be able to measure it" (BERGER; NASR, 1998, p. 27). The focus of models developed by the authors is to determine the net contribution margin. Morgan (2012) suggests some theoretical 
thought on possibilities for demonstrating business performance and points out that any way of measuring results should be understood within a reinvestment model. This situation is important, especially in competitive markets in which the search for innovation and value is constant.

The model proposed by Ryals (2005) can be understood as the generic form of revenue minus costs, both historical and projected. The resulting index is considered the value of the customer. Thus, the proposed research sought for a way of measuring relationship duration, based on revenue produced by the customer - that is, the LTR (Lifetime Revenue).

According to Bolton (1998), in the 1990s both scholars and companies increasingly sought for ways of monitoring financial and nonfinancial performances. In the literature review of Yeung and Ennew (2000), the relationship between satisfaction and profitability is considered "acceptable". Several authors also confirm this relationship, although recognizing the need for research that demonstrates it more directly; they are: Reichheld and Sasser (1990), Fornell (1992), Anderson, Fornell and Lehmann (1994), Taylor and Baker (1994) and Gurau and Ranchhod (2002). Thus, within the expected positive relationship between loyalty and financial revenues, the last studied hypothesis can be observed:
The difficulty of measuring and connecting these financial and non-financial variables is included in literature, however: “(...) clearly, an issue for debate is the choice of measures of financial performance, given the different interpretations and meanings of these measures". (YEUNG; ENNEW, 2000, p. 315)

Sampaio et al. (2011) tested, via structural modeling, Brazilian managers' perceptions of metrics that are most relevant to marketing. Consumers' perception (satisfaction and commitment, for example) was considered the most relevant, followed by financial indexes such as ROI, sales and profitability. Morgan (2012) also points out a similar situation and argues that consumers' perception and financial results are part of a learning and reinvestment model to achieve long-term profitability. Remember that perception comes before attitudes, and that these, in turn, come before behavior.

\subsection{Proposed model}

Considering the concepts and relationships presented between variables used in this research, in Figure 1 we present our proposed model, which sought to identify the impact of relationship quality and loyalty on the financial result index.
H7: The greater the level of loyalty, the greater the consumer financial result index is to the company. 


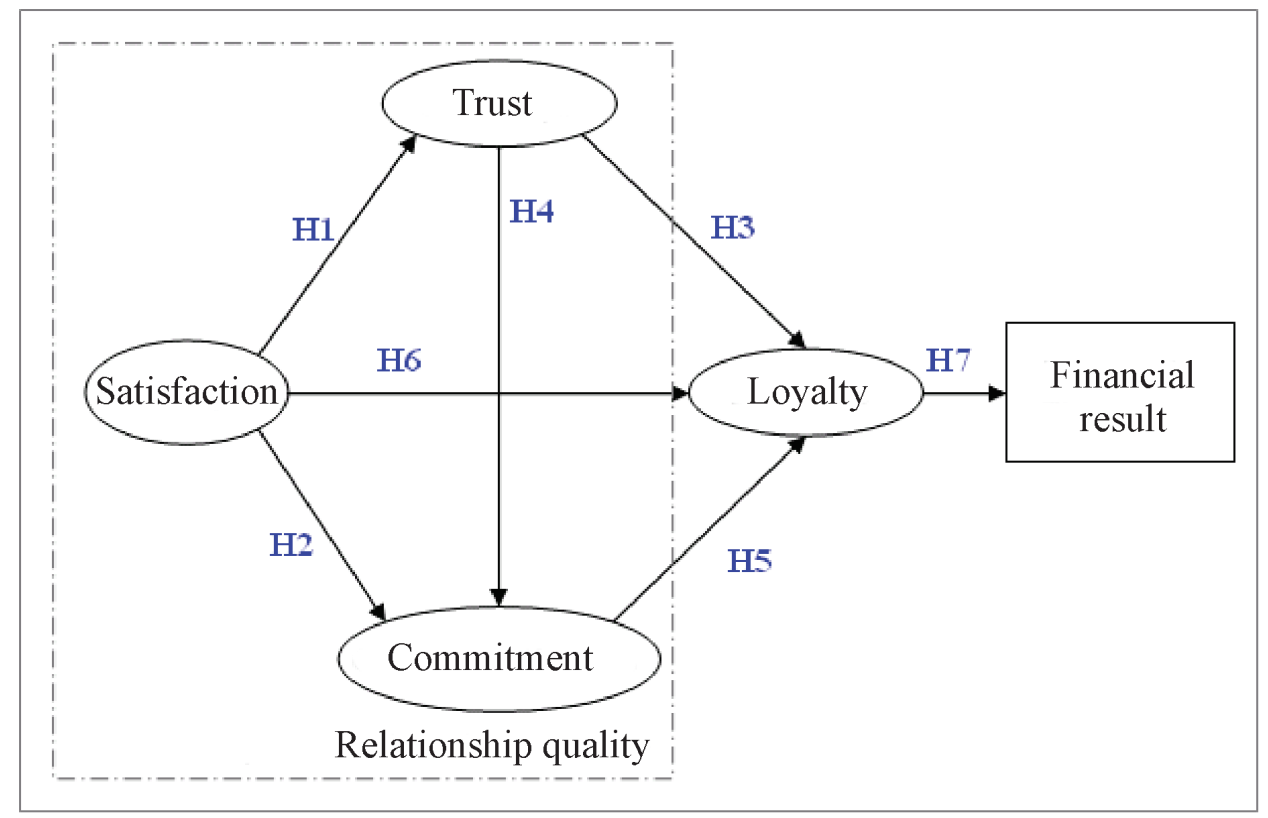

Figure 1 - Proposed study model.

Source: the authors.

In order to make measuring variables operational, scales of satisfaction (4 items), trust (7 items), commitment (9 items) and loyalty (6 items) were adapted to this research, as suggested by Prado (2004). To measure the financial result index, an adjustment was made to the model proposed by Ryals (2005), considering information available for making the calculation.

\section{METHODOLOGY}

This research is a cross-sectional survey (MALHOTRA, 2006). The survey is quantitativedescriptive and the method applied is hypotheticaldeductive (GILL; JOHNSON, 1997). The analysis unit is established by the consumer.

So as to make research feasible, the sampling procedure used was non-probabilistic; a convenience sampling technique was also employed, as defined by Malhotra (2006). To establish the amount of observations to be carried out in this research, we considered the minimum necessary for a structural equation modeling (SEM) - that is, the analysis technique to be used in the study. In a more adequate situation, Hair Junior et al. (2005) suggests 10 observations per measured index. Therefore, in this study, this would mean at least 260 .

Collection instrument content validation was carried out by 10 evaluators - four of them executives from the mobile phone field, three researchers and three consumers.

\section{RESULTS}

Results are presented in the following order: sample characterization, verification of the measurement model for the proposed structural analysis, definition of financial result index calculation and verification of the proposed structural model by means of structural equations.

\section{I Sample characterization}

From a total 493 valid responses obtained, $58 \%$ (288) referred to prepaid mobile consumers, and $42 \%$ (205) to postpaid mobile consumers. Gender distribution amongst types of mobile was predominantly and significantly of women 
amongst the prepaid $(\mathrm{T}=48.808, \mathrm{p}<0.001)$ and of men amongst the postpaid $(T=44.012$, $\mathrm{p}<0.001)$. Table 1 summarizes this stage of characterization:

Table 1 - Sample characterization.

\begin{tabular}{|c|c|c|c|c|}
\hline & & Total & Prepaid & Postpaid \\
\hline \multicolumn{2}{|l|}{ Valid cases } & $493(100 \%)$ & $288(58 \%)$ & 205 (42\%) \\
\hline \multirow{2}{*}{ Gender } & Men & $47 \%$ & $42 \%$ & $54 \%$ \\
\hline & Women & $53 \%$ & $58 \%$ & $46 \%$ \\
\hline \multirow{2}{*}{ Critério Brasil } & $A$ and $B$ & $73 \%$ & $73 \%$ & $89 \%$ \\
\hline & $\mathrm{C}$ and $\mathrm{D}$ & $27 \%$ & $27 \%$ & $11 \%$ \\
\hline \multirow{4}{*}{ Operator } & Oi & $11 \%(54)$ & $65 \%$ & $35 \%$ \\
\hline & Claro & $16 \%(78)$ & $66 \%$ & $33 \%$ \\
\hline & Tim & $51 \%(253)$ & $55 \%$ & $45 \%$ \\
\hline & Vivo & $22 \%(108)$ & $56 \%$ & $44 \%$ \\
\hline \multicolumn{2}{|c|}{ Relationship duration } & $\begin{array}{l}49.2 \text { months } \\
(\mathrm{sd}=34.944)\end{array}$ & $\begin{array}{l}41.8 \text { months } \\
(\mathrm{sd}=27.598)\end{array}$ & $\begin{array}{l}59.6 \text { months } \\
(\mathrm{sd}=41.091)\end{array}$ \\
\hline \multicolumn{2}{|c|}{ Recharging value (monthly) } & $\mathrm{R} \$ 76.50$ & $\begin{array}{c}\mathrm{R} \$ 25.00 \\
(\mathrm{sd}=11.150)\end{array}$ & $\begin{array}{c}\mathrm{R} \$ 128.00 \\
(\mathrm{sd}=91.348)\end{array}$ \\
\hline
\end{tabular}

Source: the authors.

Amongst the total consumers who responded, 53\% were women and 47\%, men. Characterization of purchasing power, according to Critério Brasil, indicated 38\% B2, 27\% B1, $26 \%$ C, $7 \%$ and $1 \%$ D A2 and A1 1\%. Regarding the proportion of operators in the base, $51 \%$ of cases were Tim, 22\% Vivo, 16\% Claro and 11\% Oi. Amongst operators, there was a had a higher concentration of postpaid customers in Tim and of prepaid customers in Claro. This information was proportional to the total presence of each operator in the base.

Although standard deviation demonstrates a large variability (and heterogeneity) in the sample studied, the average duration of the consumer's relationship with each operator was 49.2 months $(\mathrm{sd}=34.944)-41.8(\mathrm{sd}=27.598)$ for prepaid and 59.6 ( $\mathrm{sd}=41.091$ ) for postpaid. The monthly contribution stated by prepaid consumers was of $\mathrm{R} \$ 25.00(\mathrm{sd}=11.150)$. Amongst postpaid consumers, it was of $\mathrm{R} \$ 128.00$ $(s d=91.348)$.

Concerning history, $56 \%$ of the 493 evaluators have already had more than one operator. Thus, data was obtained considering the relationship with the current operator. The mentioned intention of changing revealed that $69 \%$ of consumers had already thought of changing operators. Amongst these, 69\% (308 consumers), $55 \%$ would possibly change in less than 6 months, and $37 \%$ possibly in one year.

\subsection{Data Preparation and Model Verification}

No significant differences between post and prepaid consumers were observed in the descriptive inspection of model constructs' assessments. This result contributed to the verification of the model with the total base, since the initial goal was not to separately examine characteristics such as type of phone or operator.

The result of confirmatory factorial analysis confirmed the one-dimensional character of satisfaction (alpha 0.912) and loyalty (alpha 0.896). Trust and commitment rejected the proposed multidimensional character and accepted a single dimension, with respective 0.896 and 0.912 alphas. This measurement's reliability values are presented in Table 2: 
Table 2 - Convergent reliability and validity indexes resulting from confirmatory factorial analysis.

\begin{tabular}{l|c|c|c|c}
\hline Indexes / Constructs & Satisfaction & Commitment & Trust & Loyalty \\
\hline Cronbach's Alpha & 0.912 & 0.896 & 0.912 & 0.896 \\
\hline Composite Reliability & 0.932 & 0.841 & 0.891 & 0.909 \\
\hline Average Variance Extracted & $77 \%$ & $63 \%$ & $67 \%$ & $77 \%$ \\
\hline
\end{tabular}

Source: the authors.

Subsequently, 14 of the 26 initially proposed indexes were kept at best model adjustment value. We also observed the values of composite reliability (CONF), which should be above 0.7 , and of average variance extracted (AVE), which should be above 0.5 (HAIR JUNIOR et al., 2005), as indexes of convergent validity. Results obtained were considered plausible for analysis carried out. Key validity was evaluated by means of the correlation of variables in pairs, then observing the difference between the free and the fixed chi-square (1). Acceptable values should be smaller than 3.5.

Results revealed that there was no construct overlapping. The same procedure was observed in Moura (2005). The structural model adjustment indexes, still considering only latent variables, was satisfactory and acceptable according to Hair et al. (2005): $\mathrm{X} 2=444.760, \mathrm{GL}=84, \mathrm{p}<0.001$, $\mathrm{X} 2 / \mathrm{GL}=5.295, \mathrm{NFI}=0.928, \mathrm{CFI}=0.941$ and RMSEA $=0.09$.

\subsection{Financial result index}

To define the financial result index, facing limitations found in the field (the impossibility of having direct access, in the operator, to customer history), we considered only the revenue declared by the consumer in the following conditions:

1. The revenue value corresponded to the sum of the average monthly contribution projected historically (declared duration of consumer relationship with the company), with the sum of the average projected value (based on information concerning the intent to continue with the operator). For the calculation, we used the future value (calculated historical values) and the present value (projected value of contribution) financial formulas, respectively. The discount rate used was the Selic interest rate in both cases (historical and projected). We recognize the limitation that these simplifications lend to the proposed index, however, according to Gupta (2006), operations with a high level of complexity often make their practical use unfeasible.

2. So as to define the projected period of continuity, we investigated customers' declared intention in an interval scale, with four reply options, as follows: (1) possibly, in less than 6 months, (2) possibly, in one year, (3) possibly, in 2 years, (4) possibly, in more than 2 years' time. Values in months considered for calculation were, respectively: 6, 12, 24 and 36. Thus, time was treated just as expectation of permanence.

With this information, the following calculation was used to produce the financial result index employed in this research:

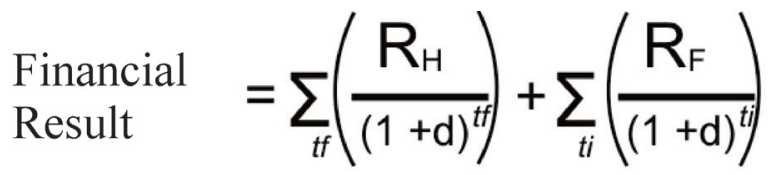

Whence,

$\mathrm{RH}=$ Historical revenue produced (Receita histórica gerada)

$\mathrm{RF}=$ Future revenue produced (Receita futura gerada)

$(1+\mathrm{d})=$ Discount rate $($ Taxa de desconto $)$

$\mathrm{tf}=$ historical period

$\mathrm{ti}=$ projected future period 


\subsection{Model and hypotheses tests}

The structural model was tested using four latent variables and a directly observable variable, as previously shown. The result of tested hypotheses can be seen in Table 3:

Table 3 - Estimated standard coefficients (paths) for proposed theoretical relationships in the model.

\begin{tabular}{l|c|c|c|c|c}
\hline Structural relationship & \multicolumn{3}{c}{ Standard coefficient } & $\begin{array}{c}\text { Hypothesis verification } \\
\text { status }\end{array}$ \\
\hline & Total & Prepaid & Postpaid & Hypothesis & Confirmed \\
\hline Satisfaction $\rightarrow$ Trust & $0.694^{*}$ & $0.669^{*}$ & $0.724^{*}$ & H1 & Confirmed \\
\hline Satisfaction $\rightarrow$ Commitment & $0.334^{*}$ & $0.244^{*}$ & $0.518^{*}$ & H2 & Not confirmed \\
\hline Trust $\rightarrow$ Loyalty & -0.020 & -0.170 & 0.084 & H3 & Confirmed \\
\hline Trust $\rightarrow$ Commitment & $0.676^{*}$ & $0.761^{*}$ & $0.507^{*}$ & H4 & Confirmed \\
\hline Commitment $\rightarrow$ Loyalty & $0.986^{*}$ & $0.990^{*}$ & $0.995^{*}$ & H5 & Not confirmed \\
\hline Satisfaction $\rightarrow$ Loyalty & -0.086 & -0.075 & -0.188 & H6 & Not confirmed \\
\hline Loyalty $\rightarrow$ Financial Result & -0.008 & 0.027 & -0.078 & H7 & H
\end{tabular}

Source: the authors based on project data.

* Significant results at 0.001

The result of the model presented refers to the evaluation of the 493 cases observed. Although they did not directly correspond to the goal of the research, we also separated and tested line types (prepaid and postpaid). Results obtained revealed the same confirmation and non-confirmation situation for studied hypotheses.

Thus, hypotheses 1, 2 and 4 - that respond to Prado's proposal (2004) concerning relationship quality - were proven. Garbarino and Johnson (1999) highlight the possible complementarity between these variables, making the positive and significant relationship between satisfaction, trust and commitment a plausible one.

Hypothesis 3, which predicted a positive and significant relationship between trust and loyalty, was not confirmed $(\beta=-0.020, \mathrm{p}=$ -0.135). To Oliver (1999), continuity of the company-consumer relationship occurs partly due to believing that this choice is the most appropriate. Then, confidence in the brand, the company or the image (for example) would be strong indexes of loyalty to it. Although this relationship was denied within the mobile environment, it may be explained, however, by Brazilian context itself, if certain elements are considered - such as high complaint rates in all of the country's active operators.

Certain papers, such as Liang, Ma and Qi (2012) include different variables - such as competition, ethical problems, questions of impropriety, amongst others - in the assessment model of service quality in the Chinese mobile phone industry, so as to measure problems in the sector. This implies that, although in different countries, the telephone industry faces similar problems concerning customer complaints. This challenges company credibility, in view of problems commonly experienced and reported by many consumers.

The relationship between commitment and loyalty (H5) was confirmed $(\beta=0.986$, $\mathrm{p}<0.001)$. This result agrees with Grönroos (1990), by confirming the importance of this construct to the continuity of a relationship, and also with Oliver (1999), by proposing an understanding of loyalty in phases - in which the greater the commitment, the greater the 
likelihood of leading affective or conative loyalty to active loyalty.

As well as hypotheses testing, we also observed construct defining coefficients $\left(\mathrm{R}^{2}\right)$, so as to verify the explanatory performance of each variable used. For the second order construct relationship quality, latent variables commitment (83\%), satisfaction (77\%) and trust (52\%) presented good performances, respectively. These values were higher than those found in Zancan (2005).

By observing the importance of relationships that come before commitment, construct with higher $\mathrm{R}^{2}$, we realize that trust $(\beta=0.676, p<0.001)$ has greater influence than satisfaction $(\beta=0.334, \mathrm{p}<0.001)$. This result demonstrates that, to strengthen customer commitment, trust is basis to be considered.

Hypothesis 6, which associated satisfaction with loyalty, unlike many studies that associated these variables, was also not confirmed ( $\beta=-0.086, p=$ insignificant). Despite studies such as McDougall and Levesque (2000), Hurley and Estelami (1998), Baptista (2005) and Baptista, Silva and Goss (2011), which empirically proved the positive and significant association between satisfaction and the intention of purchasing and continuing in the relationship - indexes of individuals' loyalty -, it is relevant to mention that this association is found in literature in a controversial way. Some authors, such as Jones and Sasser (1995), comment on a connection that is not necessarily linear (satisfaction $\rightarrow$ loyalty). Moreover, these authors comment that environmental characteristics such as the high cost of changing operators, promotional benefits and government regulations are factors that stimulate false loyalty and a "weak" relationship with satisfaction, since, in this context, the duration of the relationship is not defined solely by consumers' choice, but by other variables that offer convenience or certain limitations.

The loyalty defining coefficient was of $80 \%$. This value refers basically to the direct impact of commitment, triggered by trust and satisfaction. According to the indexes used, incentives that stimulate the desire to continue in the relationship (such as promotions), demonstrating to customers that the company is willing to assist them (such as with service quality and customized solutions), and support to a feeling of partnership between company and customer (strengthening the company's image as a partner, for example) are possibilities for intensifying commitment and, therefore, stimulating consumer loyalty.

In the seventh hypothesis we expected a positive relationship between loyalty and the financial result index, as stated in previous studies (YEUNG; ENNEW, 2000; JOHNSON et al., 2001; GUO; JIRAPORN, 2005). This relationship, however, was not observed in our research. Gurau and Ranchhod (2002) commented on how difficult it is to obtain a positive relationship considering the subjectivity of latent variables' measurement and the bias that data crossing may have given to some other factor.

In order to explore results obtained in testing hypothesis 7 , we separated prepaid and postpaid mobile consumers to check if the line type could influence these results.

The results of post-paid $(\beta=-0.078$, $\mathrm{p}=-1.091)$ and prepaid $(\beta=0.027, \mathrm{p}=0.443)$ once again denied the direct and linear relationship between loyalty and financial results. To visualize this result, graphs 1 and 2 show the dispersion of answers when crossing the financial result index (LTV) with a weighted score of the latent variable loyalty amongst line types: prepaid and postpaid. 


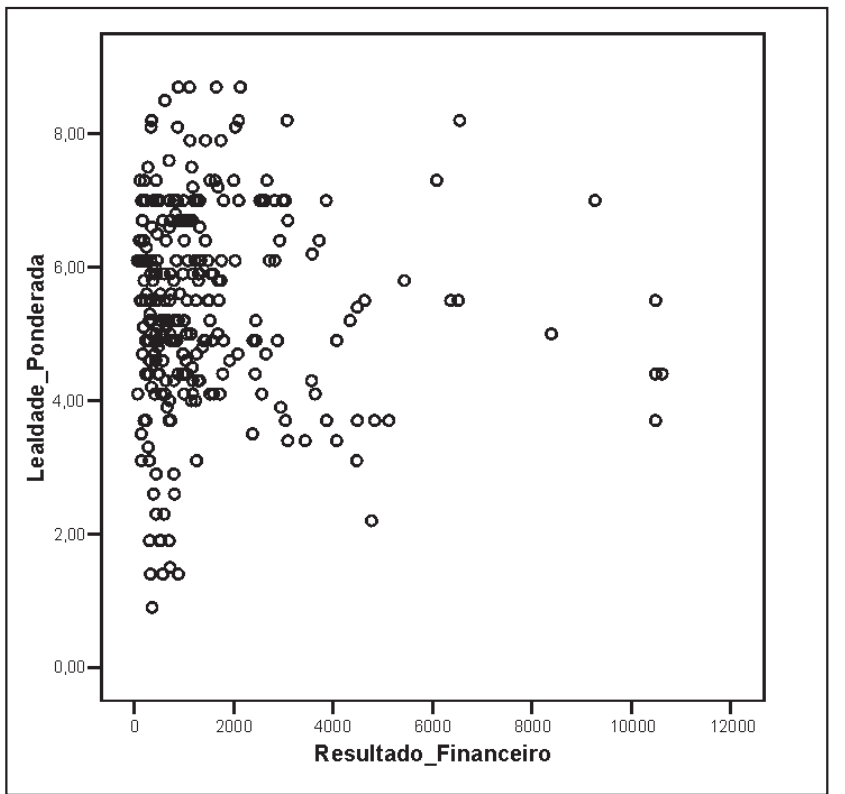

Graph 1 - Financial result and loyalty: prepaid.

Source: the authors based on project data.

To complement visual information from the graphs, Table 4 presents the value of correlations between variables. Also included are correlations between rates of financial revenues

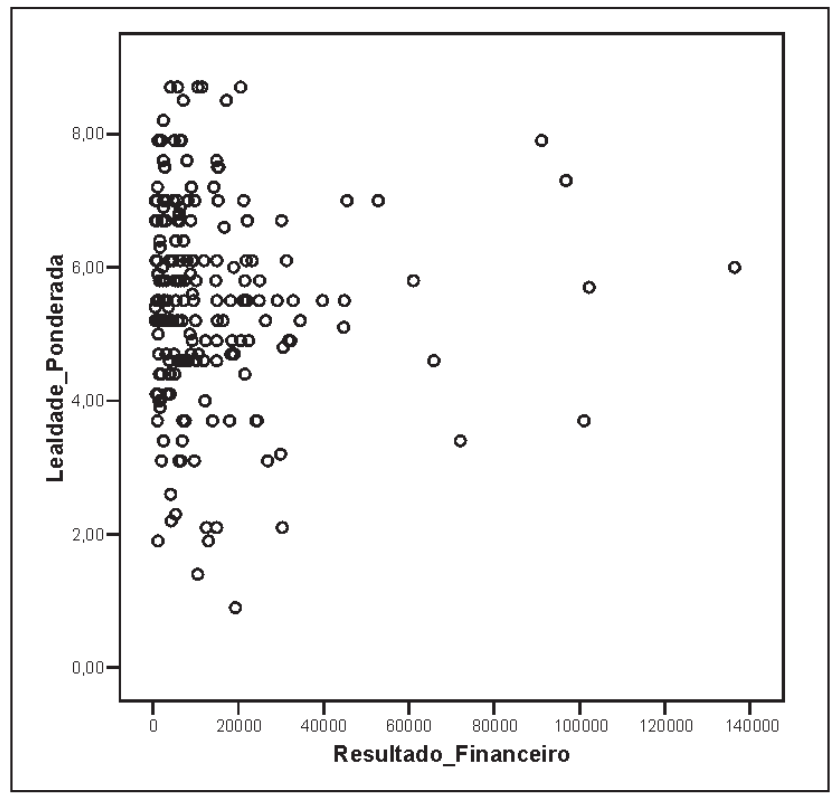

Graph 2 - Financial result and loyalty: postpaid.

Source: the authors based on project data.

and weighted scores obtained between the latent variables that make up the relationship quality construct.

Table 4 - Correlation between financial revenue and latent variables.

\begin{tabular}{l|l|l}
\hline Established correlations & $\begin{array}{l}\text { Results } \\
\text { PREPAID }\end{array}$ & $\begin{array}{l}\text { Results } \\
\text { POSTPAID }\end{array}$ \\
\hline Financial revenue and loyalty & $\mathrm{r}=-0.004, \mathrm{p}=0.941$ & $\mathrm{r}=-0.013, \mathrm{p}=0.855$ \\
\hline Financial revenue and satisfaction & $\mathrm{r}=-0.086, \mathrm{p}=0.144$ & $\mathrm{r}=0.022, \mathrm{p}=0.759$ \\
\hline Financial revenue and trust & $\mathrm{r}=0.051, \mathrm{p}=0.393$ & $\mathrm{r}=-0.089, \mathrm{p}=0.202$ \\
\hline Financial revenue and commitment & $\mathrm{r}=0.042, \mathrm{p}=0.144$ & $\mathrm{r}=0.031, \mathrm{p}=0.655$ \\
\hline
\end{tabular}

Source: the authors based on project data.

These numbers reveal that, regardless of the type of mobile line, there was no correlation between variables. However, this statement could also raise suspicions that values are different between operators and that some specific result may have influenced the general, since all companies were grouped together. In this way, as well as no distinction between types of line having been observed, Table 5 reveals that there was also no relationship between operators present in the researched base. 
Table 5 - Correlation between financial revenue and latent variables - by operator.

\begin{tabular}{l|l|l|l|l}
\hline $\begin{array}{l}\text { Established } \\
\text { correlations }\end{array}$ & OI & CLARO & TIM & VIVO \\
\hline $\mathrm{FR}^{*}$ and loyalty & $\mathrm{r}=0.082, \mathrm{p}=0.554$ & $\mathrm{r}=0.062, \mathrm{p}=0.590$ & $\mathrm{r}=-0.024, \mathrm{p}=0.708$ & $\mathrm{r}=0.051, \mathrm{p}=0.600$ \\
\hline $\mathrm{FR}^{*}$ and satisfaction & $\mathrm{r}=0.035, \mathrm{p}=0.802$ & $\mathrm{r}=0.107, \mathrm{p}=0.350$ & $\mathrm{r}=-0.013, \mathrm{p}=0.834$ & $\mathrm{r}=0.053, \mathrm{p}=0.584$ \\
\hline $\mathrm{FR}^{*}$ and trust & $\mathrm{r}=0.225, \mathrm{p}=0.102$ & $\mathrm{r}=0.068, \mathrm{p}=0.557$ & $\mathrm{r}=-0.073, \mathrm{p}=0.249$ & $\mathrm{r}=-0.097, \mathrm{p}=0.320$ \\
\hline $\mathrm{FR}^{*}$ and commitment & $\mathrm{r}=0.113, \mathrm{p}=0.417$ & $\mathrm{r}=0.099, \mathrm{p}=0.389$ & $\mathrm{r}=-0.010, \mathrm{p}=0.877$ & $\mathrm{r}=0.102, \mathrm{p}=0.291$ \\
\hline
\end{tabular}

Source: the authors based on project data.

${ }^{*}$ Financial result

\section{DISCUSSION OF RESULTS}

Regarding this study's first goal, a positive and significant relationship between the constructs of relationship quality was confirmed, according to Prado's proposal (2004), which proves the robustness of the model, if applied to different contexts. However, satisfaction and trust were not observed as key (at least for the group analyzed) to loyalty, as predicted in literature (OLIVER, 1999). We found no positive expectation of relationship continuity simply because customers are satisfied or trust the operator. The opposite was observed in Moura (2005) when testing the ACSI index in the mobile sector, specifically in the state of Minas Gerais. In the study, the author demonstrates the positive and relevant relationship between variables.

This demonstrates that further research is still necessary to investigate and deepen understanding on the subject. It may be that territoriality has affected the completion of analysis. Still according to the work of Moura (2005), averages obtained to measure satisfaction were higher than those recorded in this research. As well as state specificity, other variants such as using a 5-point Likert scale may have been key to the contrast of results obtained.

Furthermore, as mentioned in analysis, some sector characteristics such as the high cost of changing operators, promotional (dis)advantages and high levels of complaint at the Brazilian official customer complaint agency (Procon) are also indications that favor a "weak" a relationship with satisfaction and/or a false loyalty, according to Oliver's proposition (1999).

Regarding this study's second goal, the proposed measure of the financial result's declared value is genuine to this research. The value obtained is an estimate reported by each customer - a fact which allows for exploring some different scenarios, in view of the period of continuity with the provider.

As to the third and final goal, although there is in literature the expectation that satisfied customers would be less price sensitive (ANDERSON, 1996), Zeithaml, Berry and Parasuraman (1996) claim that this "lack of price sensitivity" can behave differently in specific contexts. This fact is mentioned because the test trial amongst prepaid and postpaid consumer groups and between competing operators could clarify certain specific relationships, such as: higher consumption groups might be more likely to be loyal (non-financial result). These speculations, however, were not demonstrated in any case.

This situation implies a new way of thinking about the management of the customer base in this sector. Consumers seem very sensitive to prices and offers posted by competing operators. Thus, as well as the adequate service to be provided, operators must invest in differential items that produce perceived value to the consumer. We recall that advertising is not the only one responsible for defining a company's position. Therefore, companies should invest in technology and take a sustainable position to 
unleash the perceived value and differential. If the differential is still the price per minute or only the benefits of a specific promotion, the churn rate will possibly remain unaltered, and the value of each customer, reduced.

Thus, to obtain a more accurate assessment of the financial and non-financial results in the mobile service retail, we suggest that service quality and customer care be intensified.

We recall that the main benefit purchased by the consumer is not the promotion itself, but the mobile service and technology to solve the potential problem of communication between people. After all, increasing the perceived and financial value of a company's current customers costs less than conquering the perceived and financial value of new consumers (ZEITHAML; BERRY; PARASURAMAN, 1996; YEUNG; ENNEW, 2000; YI; JEON, 2003).

\section{CONCLUSIONS}

Considering discussions presented for each objective and results found, it is possible to consider that, in the Brazilian context, the mobile industry presents certain particularities as to evaluating proposed variables. One of the indexes demonstrating this possibility is the assessment homogeneity amongst the four evaluated operators, even though heterogeneity was observed in the sample. This implies recognizing that no significant difference was observed in the assessment of consumers who answered (considering differences in age, gender and income), regardless of the operator. All of them registered medium assessment values. This evaluation parity suggests the urgent need for strategies that effectively provide differentiation in services offered.

Finally, the "no evidence" of the relationship between satisfaction and loyalty and financial results, even facing methodological constraints, emphasizes the (possible) non-linear behavior of these variables and suggests the need for further studies to explore this condition.
From the theoretical point of view, the paper's main contribution was to test a model with financial and non-financial variables; to define LTR data by means of declared by the consumer; and proof of the non-linear structure between satisfaction, loyalty and LTR.

Its main practical contribution practice, thought on the competitiveness of the sector and service homogenization, is commonplace in everyday experiences. Thus, we gave space for the line of thought that aggregates the explanation of the indirect impact of satisfaction and trust on loyalty, as well as non-linear structures that connect the favorable perception of the company by more profitable individuals in the business relationship. This implies that investment in structures that subsidize satisfaction (resources for better services, better services, greater clarity in bills, for example, amongst others) is associated with a part in the chain of impact on loyalty.

Some of the study's limitations result from methodological aspects, such as the lack of official basis in customer data. This situation led the calculated LTR to be based on declared average monthly contribution values. The duration of the relationship with the line and the permanence potential were also declared and calculated according to consumers' memories. Future studies may rely on other financial structures that are capable of observing details about the services employed (such as calls, sms, mms, shopping services, amongst others).

The structure of the theoretical model can also be more adapted to the context of the mobile phone industry and include analysis issues such as convenience, consumer complaints and sector competition, amongst others, as suggested by Liang, Ma and Qi (2012).

\section{REFERENCES}

ANDERSON, E. Customer satisfaction and price tolerance. Marketing Letters, Norwell, v. 7, n. 3, p. 265-274, July 1996.

ANDERSON, E. W.; FORNELL, C.; LEHMANN, D. R. Customer satisfaction, 
market share, and profitability: findings from sweden. Journal of Marketing, Chicago, v. 58, n. 3, p. 53-66, July 1994.

BAPTISTA, P. P. Lealdade do consumidor e os seus antecedentes: um estudo aplicado ao setor varejista na internet. 2005. 194 f. Tese (Doutorado em Administração) - Programa de Pós-Graduação em Faculdade de Economia, Administração e Contabilidade - Universidade de São Paulo - USP, São Paulo, 2005.

; SILVA, W. V.; GOSS, L. P. Qualidade percebida e seus impactos sobre a satisfação, confiança e lealdade: um estudo com varejistas eletrônicos de serviços de download gratuito. Revista de Ciências da Administração, Florianópolis, v. 13, n. 30, p. 249-277, maio/ ago. 2011.

BERGER, P. D.; NASR, N. I. Customer lifetime value: marketing models and applications. Journal of Interactive Marketing, New York, v. 12, n. 1, p. 17-30, Winter 1998.

BOLTON, R. N. A dynamic model of the duration of the customer's relationship with a continuous service provider: the role of satisfaction. Marketing Science, Linthicum, v. 17, n. 1, p. 45-65, Winter 1998.

CALCIU, M.; SALERMO, F. Customer value modelling: synthesis and extension proposals. Journal of Targeting, Measurement and Analysis for Marketing, London, v. 11, n. 2, p. 124-147, Sept. 2002.

DWYER, F. R.; SCHURR, P. H.; OH, S. Developing buyer-seller relationships. Journal of Marketing, Chicago, v. 61, n. 2, p. 11-27, Apr. 1987.

ENGEL, J. F; BLACKWELL, R. D; MINIARD, P. W. Comportamento do consumidor. 8. ed. Rio de Janeiro: LTC, 2000.

FORNELL, C. A National customer satisfaction barometer: the Swedish experience. Journal of
Marketing, Chicago, v. 56, n. 1, p. 6-21, Jan. 1992.

GARBARINO, E.; JOHNSON, M. S. The different roles of satisfaction, trust, and commitment in customer relationships. Journal of Marketing, Chicago, v. 63, n. 2, p. 70-87, Apr. 1999.

\section{GILL, J.; JOHNSON, P. Research methods for} managers. 2. ed. London: Sage, 1997.

GRÖNROOS, C. Relationship approach to the marketing function in service contexts: the marketing and organizational behavior interface. Journal of Business Research, New York, v. 20, n. 1, p. 3-11, Jan. 1990.

GUO, C.; JIRAPORN, P. Customer satisfaction, net income and total assets: an exploratory study. Journal of Targeting, Measurement and Analysis for Marketing, London, v. 13, n. 4, p. 346-353, July 2005.

GUPTA, S. Managing customers as investments: the strategic value of customers in the long run. Upper Saddle River, NJ: Wharton School Publishing, 2006.

GURAU, C.; RANCHHOD, A. How to calculate the value of a Customer. Measuring customer satisfaction: a platform for calculating, predicting and increasing customer profitability. Journal of Targeting, Measurement an Analysis for Marketing, London, v. 10, n. 3, p. 203-219, Feb. 2002.

HAIR JUNIOR, J. F. et al. Análise multivariada de dados. 5. ed. Porto Alegre: Bookman, 2005.

HENNING-THURAU, T.; KLEE, A. The impact of customer satisfaction and relationship quality on customer retention: a critical reassessment and model development. Psychology \& Marketing, New York, v. 14, n. 8, p. 737-764, Dec. 1997.

HURLEY, R. H.; ESTELAMI, H. Alternative indices for monitoring customer perceptions of service quality: a comparative evaluation in a retail 
context. Journal of the Academy of Marketing

Science, Thousand Oaks, v. 26, n. 3, p. 209-221, Summer 1998.

JOHNSON, M. D. et al. The evolution and future of national customer satisfaction index models. Journal of Economic Psychology, Amsterdam, v. 22, n. 2, p. 217-245, Apr. 2001.

JONES, O. T.; SASSER, W. E. Why satisfied customers defect. Harvard Business Review, Boston, n. 73, p. 87-100, Nov. 1995.

KOTLER, P. Administração de marketing: a edição do novo milênio. 10. ed. São Paulo: Prentice Hall, 2000.

LIANG, D.; MA, Z.; QI, L.Service quality and customer switching behavior in China's mobile phone service setor. Journal of Business Research, New York, 2012. In press.

MALHOTRA, N. K. Pesquisa de marketing: uma orientação aplicada. 4. ed. Porto Alegre: Bookman, 2006.

MAVONDO, F. T.; RODRIGO, E. M. The effect of relationship dimensions on interpersonal and interorganizational commitment in organizations conducting business between Australia and China. Journal of Business Research, New York, n. 52, n. 2, p. 111-121, May 2001.

MCDOUGALL, G. H. G.; LEVESQUE, T. Customer satisfaction with services: putting perceived value into the equation. The Journal of Services Marketing, Bradford, v. 14, n. 5, p. 392-410, Sept. 2000.

MORGAN, N. A. Marketing and business performance. Journal of the Academy of Marketing Science, Thousand Oaks, v. 40, n. 1, p. 102-119, Jan. 2012.

MORGAN, R.; HUNT, S. The commitment trust theory of relationship marketing. Journal of Marketing, Chicago, v. 45, n. 3, p. 20-38, July 1994.
MOURA, A. C. Validação do modelo de satisfação ACSI modificado no setor de telefonia móvel. In: ENCONTRO NACIONAL DA ASSOCIAÇÃO NACIONAL DOS PROGRAMAS DE PÓSGRADUAÇÃO EM ADMINISTRAÇÃO, 29., 2005, Brasília. Anais... Brasília: ANPAD, 2005. p. 141-157.

OLIVER, R. L. Measurement and evaluation of satisfaction process in retail settings. Journal of Retailing, New York, v. 57, n. 3, p. 25-48, 1981. Whence consumer loyalty? Journal of Marketing, Chicago, v. 63, special issue, p. 3344, Dec. 1999.

PARENTE, J. Varejo no Brasil: gestão estratégica. São Paulo: Atlas, 2000.

PRADO, P. H. M. A avaliaçáo do relacionamento sob a ótica do cliente: um estudo em bancos de varejo. 2004. 480 f. Tese (Doutorado em Administração de empresas) - Fundação Getúlio Vargas, São Paulo, 2004.

REICHHELD, F. F.; SASSER, W. E. Zero defections: quality comes to services. Harvard Business Review, Boston, v. 68, n. 5, p. 105-111, Sept. 1990.

REINARTZ, W. J.; KUMAR, V. The impact of customer relationship characteristics on profitable lifetime duration. Journal of Marketing, Chicago, v. 67, n. 1, p. 77-99, Jan. 2003.

RYALS, L. Making customer relationship management work: the measurement and profitable management of customer relationships. Journal of Marketing, Chicago, v. 68, n. 4, p. 252-261, Oct. 2005.

SAMPAIO, C. H. et al. Marketing metrics: insights from Brazilian managers. Industrial Marketing Management, New York, v. 40, n. 1, p.8-16, Jan. 2011.

SIDERSHMUKH, D.; SINGH, J.; SABOL, B. Consumer trust, value, and loyalty in relational exchanges. Journal of Marketing, Chicago, v. 66, n. 1, p. 15-37, Jan. 2002. 
SOLOMON, M. R. Comportamento do consumidor. 5. ed. São Paulo: Bookman, 2002.

TAYLOR, S. A; BAKER, T. L. An assessment of the relationship between service quality and customer satisfaction in the formation of customer purchase intention. Journal of Retailing, New York, n. 70, p. 163-179, 1994.

STEWART, D. W. Marketing accountability: linking marketing actions to financial results. Journal of Business Research, New York, v. 62, n. 6, p. 636-643, June 2009.

TELECO. Informaçóes em telecomunicaçóes. [2011]. Disponível em: <www.teleco.com.br>. Acesso em: 10 dez. 2011.

WILSON, D. T. An integrated model of buyerseller relationships. Journal of the Academy of Marketing Science, Thousand Oaks, v. 23, n. 4, p. 335-346, Sept. 1995.
YEUNG, M. C. H.; ENNEW, C. T. From customer satisfaction to profitability. Journal of Strategic Marketing, London, v. 8, n. 4, p. 313-326, 2000.

YI, Y.; JEON, H. Effects of loyalty programs on value perception, program loyalty, and brand loyalty. Journal of the Academy of Marketing Science, Thousand Oaks, v. 31, n. 3, p. 229-240, Summer 2003.

ZANCAN, C. Antecedentes e conseqüências da qualidade do relacionamento: a perspectiva de produtores da maçá brasileira. 2005. $177 \mathrm{f}$. Dissertação (Mestrado em Administração) Universidade Federal do Paraná - UFPR, Paraná, 2005.

ZEITHAML, V.A.; BERRY,L.; PARASURAMAN, A. The behavioral consequences of service quality. Journal of Marketing, Chicago, v. 60, n. 2, p. 31-46, Apr. 1996. 